\title{
Solid Waste Management for Sustainable Development and Public health: A Case Study of Lagos State in Nigeria
}

\author{
Oyebode Oluwadare Joshua
}

\author{
Afe Babalola University, Ado-Ekiti, Nigeria \\ *Corresponding Author: oyebodedare@yahoo.com
}

Copyright $(0) 2013$ Horizon Research Publishing All rights reserved.

\begin{abstract}
Public health is a fundamental requirement to human existence. Waste is directly linked to human development, both technologically and socially, some components of waste have economical value and can be recycled once correctly recovered. Effects of poor environmental hygiene on public health were studied in the precarious living quarters of Lagos state in Nigeria. This study examined the waste management; identified the challenges facing its operation; proffered possible solutions necessary for the growth of the waste market, and also the need to harness the inherent economic and environmental benefits. Data collected in various centers in the town on cases of morbidity, revealed that malaria is much contracted by populations with $58 \%$ cases against $14 \%$ for diarrhea and $28 \%$ for acute respiratory infections. Under-five children are much affected with $24 \%$ of the patients among which $43 \%$ were cases of the diarrheic diseases. Also, malaria and respiratory infections are more important during rainy seasons, in contrast to diarrheal diseases caused by poor hygiene of people. It has been ascertained that the level of education affects the public health. The concept transformation of waste from an exhausted utility to a valuable commodity as a mechanism for effective solid waste management is yet to be properly utilized in Lagos State.
\end{abstract}

Keywords Environment, Lagos State, Public Health, Respiratory Infections, Waste

\section{Introduction}

Most large African cities are overcrowded, due to urban attraction. Little controlled urban growth leads to poor management of solid and liquid wastes produced by cities. This leads to many problems of sanitation. The sanitation in these cities is generally dominated by self purification works. They often repress wastewater that trickles down in living quarter streets emitting strong foul odors (WHO, 2000). Moreover, water intended for consumption are very often contaminated because of drinking water connection with the sewage. This fact can cause high health risks and environmental pathologies arising from it are very important. They are mostly of diarrheal diseases. In addition, poor drainage of wastewater and storm water leads to the proliferation of ponds that are habitats of mosquito vectors of various diseases including malaria (OMS, 1985).

These various pathologies are the result of many interactive phenomena between health and environmental hygiene highlight many health risks associated with poor hygiene (Hibberd et al, 1998) including vector-borne diseases and infections (Forget and Lebel, 2002).

In fact, poor quality waters, poor environmental sanitation (excreta management, drainage) and poor sanitation contribute much to deteriorating population health (Ezzati et al., 2005).

The objective of this work is thus, to establish a snapshot of Lagos town in sanitation and mode of supply in drinking water in association with population health. Diseases investigated are including malaria, diarrheal diseases and acute respiratory infections (Ogedengbe, 2001).

Solid waste management has emerged as one of the greatest challenges facing state and local government environmental protection agencies in Nigeria. The volume of solid waste being generated continues to increase at a faster rate than the ability of the agencies to improve on the financial and technical resources needed to parallel this growth. Solid waste management in Nigeria is characterized by inefficient collection methods, insufficient coverage of the collection system and improper disposal of solid waste. The quantity of solid waste generated in urban areas in industrialized countries is higher than in developing countries; still municipal solid waste management remains inadequate in the latter. Solid waste in developing countries differs from developed countries. Most developing countries, including Nigeria have solid waste management problems different from those found in industrialized countries in areas of composition, density, political, and economic framework, waste amount, access to waste for collection, awareness and attitude. The wastes are heavier, wetter and more corrosive in developing cities than developed cities (Ogwueleka, 2009). 


\subsection{Study Area}

The State is located in the southwestern part of Nigeria and lies between latitude $6^{\circ} 2 \mathrm{~N}$ to $6^{\circ} 2 \mathrm{~N}$ and from longitude $2^{\circ} 45^{\prime} \mathrm{E}$ to $4^{\circ} 20^{\prime} \mathrm{E}$. It occupies a total geographical area of about $3,475.1 \mathrm{~km}^{2}$. About $787 \mathrm{~km}^{2}$ or 22 percent of Lagos territory is water. It shares its borders with Ogun State in the north and east and is bounded on the west by the Republic of Benin. In the south it stretches for $180 \mathrm{~km}$ along the coast of the Atlantic Ocean. Lagos State is in terms of geography arguably the smallest State in Nigeria. Lagos is one of the six states that make up Nigeria's South West geopolitical zone. It shares an international boundary with the Republic of Benin to the southwest and has an interstate boundary with Ogun State (LSINGO, 2011). The Bight of Benin lies to its south. Its capital is Ikeja. Figure 1 shows administrative map of the state and Figure 2 indicates the map of Lagos state.

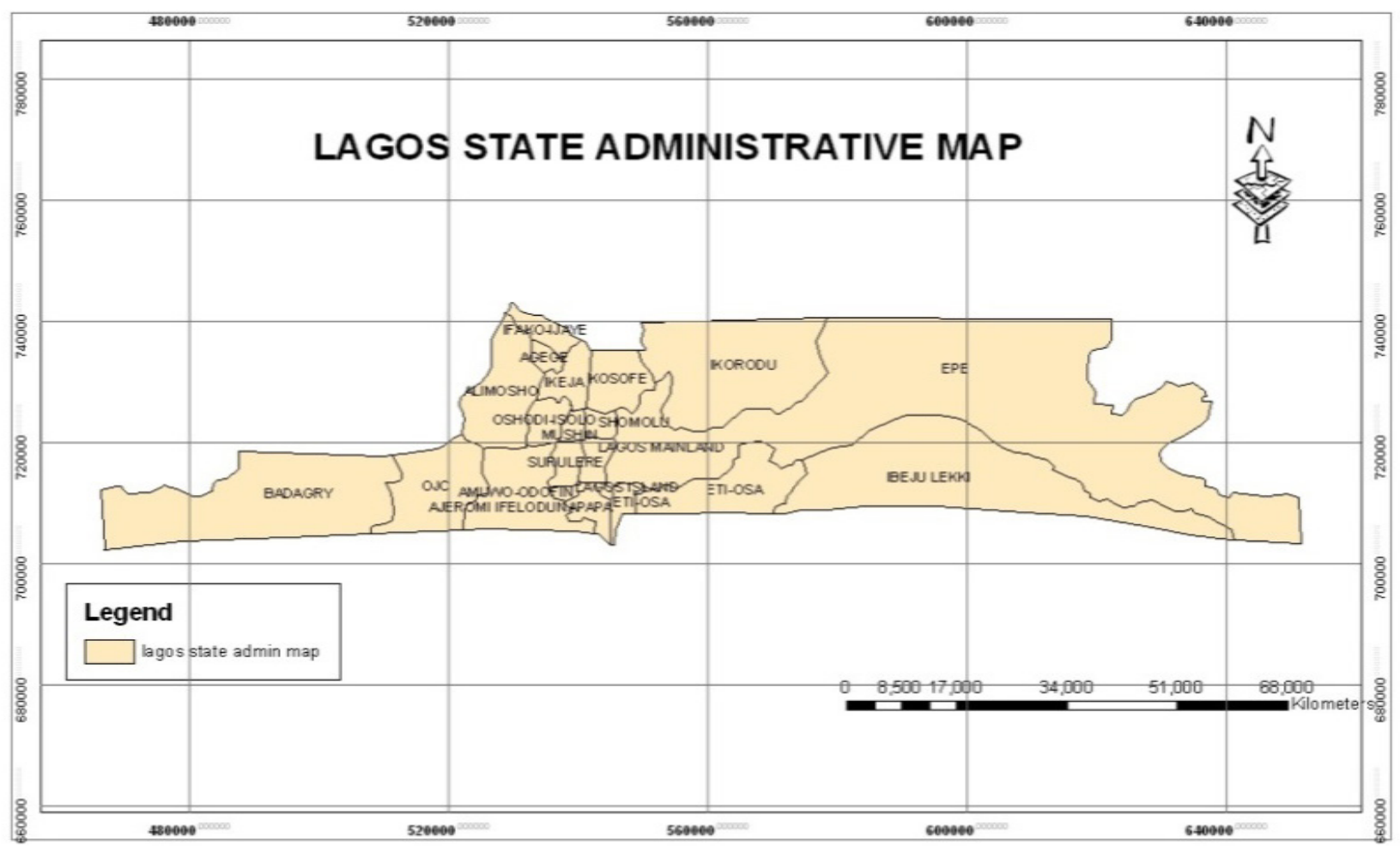

Figure 1. Lagos State Administrative Map

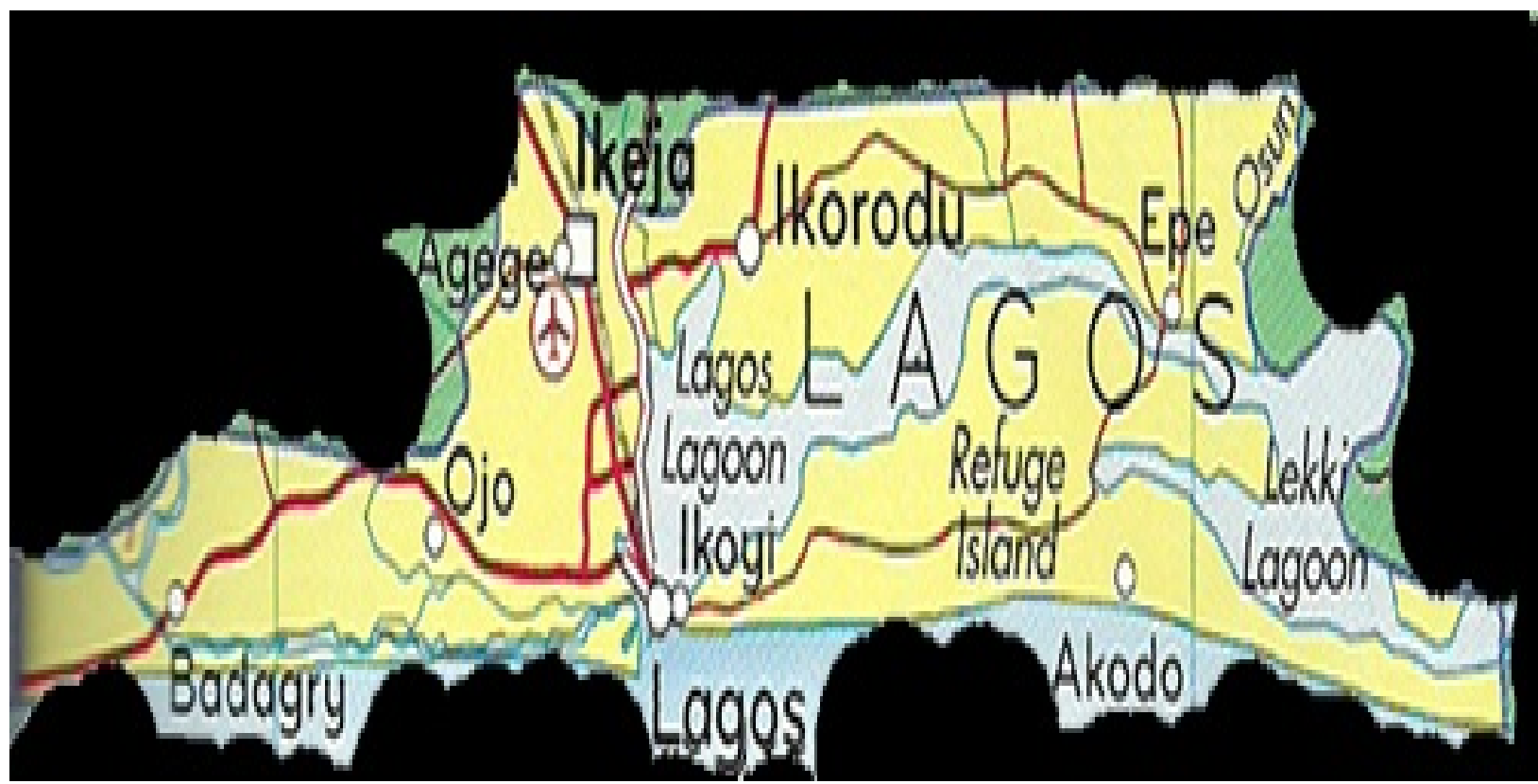

Figure 2. The map of Lagos state 


\subsection{History, Land Mass and Population of Lagos}

Lagos State was originally part of the Western Region in the three-region structure of 1954. In 1967, with the creation of twelve federal states by General Yakubu Gowon's military government, it became part of the Western State. With the creation of nineteen states from the existing twelve in 1976 by the military government of General Murtala Muhammed, Lagos was carved out of the Western State. Lagos served as the capital of Nigeria from 1914 until 1991 (when it was replaced by Abuja). Yoruba people settled in the state in large numbers early in the course of its modern development, followed by migrants from all over Nigeria and other West African nations, as well as returnee ex-slaves (known as Creoles) from Freetown, Sierra Leone, Brazil and the West Indies. The Creoles contributed significantly to Lagos's modernisation and the influence of their Portuguese heritage can still be seen in the architecture on Lagos Island.

\subsection{Administrative Structure}

There are twenty local government areas (LGAs) in the state, as well as thirty-seven local council development areas (LCDAs). Each has a chairman as its administrative head. Lagos State is an administrative division of Nigeria, located in the southwestern part of the country. The smallest in area of Nigeria's states, Lagos State is arguably the most economically important state of the country, containing Lagos, the nation's largest urban area. The actual population total is disputed between the official Nigerian Census of 2006, and a much higher figure claimed by the Lagos State Government.

The main cities and towns are Ikeja (capital), Agege, Apapa, Badagry, Epe, Ikorodu, Ikotun, Ikoyi, Ipaja, Ogudu, Ojota, Oshodi, Victoria Island and Yaba. Although Lagos is the smallest state in Nigeria geographically (with an area of 3,496 hectares, of which 75,755 hectares are wetlands), it has one of the highest populations $(9,113,605$ according to the 2006 census - over 5 percent of the national total). The UN estimates that at its present growth rate, Lagos will be third largest mega-city in the world by 2015 after Tokyo in Japan and Mumbai (Bombay) in India. It lies at latitude $6^{\circ} 27^{\prime} 11^{\prime \prime}$ north and longitude $3^{\circ} 23^{\prime} 45^{\prime \prime}$ east. Metropolitan Lagos, which accounts for 37 percent of the land area of Lagos State, is home to over 85 percent of its population.

\subsection{Waste Generated in the State}

Income and economic growth have impact on the composition of wastes. Rotich et al. (2006) established a positive relationship between income levels and waste generation at the household level as High-income earners consume more packaged products, which result in a higher percentage of inorganic materials - metals, plastics, glass, and textile. Waste characteristics vary according to season, income level, population, social behaviour, climate, and industrial production, the size of markets for waste materials and the extent of urbanization, effectiveness of recycling, and work reduction (Hoornweg et al., 1999).

Municipal solid waste composition in Lagos State varies from one settlement to another and is dependent on the level of human and industrial activates taking place in these settlements, i.e. there are variations between urban/suburban and rural residential wastes.

\section{Materials and Methods}

Data were collected through the use of a questionnaire in which questions pertaining to age, sex, level of education, occupation and issues affecting waste market operations were asked. Stratified random sampling was also used to provide appropriate representation of the societal classes in the population

The study took place in precarious living quarters, a village lagoon and modern living quarters of Lagos town. Selection of living quarters was done as part of an interdisciplinary approach to understanding global health problems in the town in relation to environment, sociology and health engineering. The investigation was performed from March 2011 to June 2013 using an investigation form. It was conducted with a team of investigators who run through the various living quarters of the town. Households responding to the questionnaires were the different samples sanitary data were collected in fifteen health centres. The information researched concerned the recurrent diseases including malaria, diarrheal diseases and acute respiratory infections. The data were collected by the information system of management, which is the monthly statement of all the activities mad in health centres. Concerning the division of the population in age, the classic range (0-4, 5-14, 15-29 and 30 years and more) used in medicine was selected.

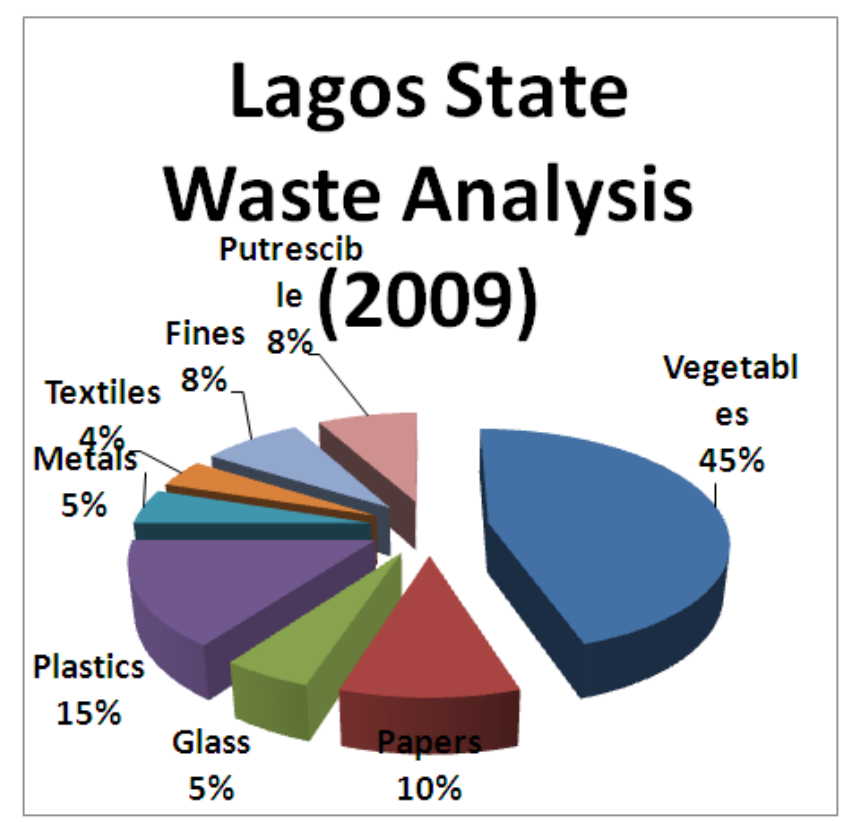

Figure 3. Lagos State Waste Analysis 
The population of Lagos State according to a recent estimate from the National Population Commission is 9,113,605- Male: 4,719,125; Female: 4,394,480, which makes it the second most populous State in Nigeria, after Kano State. Its urban section is also credited with $9.5 \mathrm{~m}$ residents under the Urban Agglomeration issued by the United Nations Department of Economic and Social Affairs (Population Division), making it the second most populous city in Africa. Lagos State is Nigeria's economic capital with over 2,000 industries located in the state. It accounts for 65 percent of the country's formal economic activities. Figure 3 indicates Lagos State waste analysis. Agricultural activities in Lagos are mainly fishing which is done on a commercial level.

\section{Results}

A total of 200 people were interviewed, with the number of respondents evenly distributed on gender basis within the age group of $18-70$ years as shown in table 1 .

Table 1. Demography Profile of Respondents

\begin{tabular}{|c|c|}
\hline Characteristics & Percentage (\%) \\
\hline Male & 51.78 \\
\hline Female & 48.22 \\
\hline Age & 20 \\
\hline 30 and below & 40 \\
\hline 31 -50 & 35 \\
\hline $51-60$ & 15 \\
\hline Above 60 & 3 \\
\hline Educational Level \\
\hline No Education & 30 \\
\hline Primary Education & 44 \\
\hline Secondary Education & 23 \\
\hline Tertiary and Above & 38 \\
\hline \multicolumn{2}{|c|}{ Main Occupation } \\
\hline Farming & 08 \\
\hline Trading & \\
\hline
\end{tabular}

The household member's literacy level by their daily activities was investigated and the underlining results were obtained: $41 \%$ of the literate household members are students, $24 \%$ constitutes the self employed while $11 \%$ comprises those on regular employment. The analysis also revealed that $4 \%$ of the literate household members are unemployed while $3 \%$ are engaged on casual/daily employment. $1 \%$ each constitutes household literate members who are engaged in unpaid household work, apprentice, pensioners and artisan respectively.

\section{Data Analysis and Discussion}

This work uses an interdisciplinary approach in studying poor sanitation and health risks. It reveals that the accessibility of population with drinking water is very important in Lagos city. According to the studies of Rotich et al. (2006), 99\% of households of the municipality of lagos were connected to the networks of drinking water. This rate approaches that of our study in Lagos town which is $90 \%$ self purification sanitation system. Excreta management is mainly $(60 \%)$ using in lagos state. The lack of sanitation contributes much to the deteriorating health of populations. Diarrheal diseases are caused by several parasites including Salmonella (most frequently occurred) and are located in unhealthy environments, lack of adequate modern sewerage system, or associated with poor environmental hygiene. This situation is much more noticeable in most cities in developing countries where poor environmental and especially section of under five children are most affected by diarrheal diseases. Our investigations lead to similar observations with a child morbidity by $26 \%$ compared to diarrheal diseases.

Moreover, the prevalence rate of malaria registered in health centers is more than twice that consultation may be more expensive than treatment after diagnosis of a modern specialist. Thus, ignorance of households on the choice of a suitable therapeutic route appears to be an economic risk factor for household towards the pathologies.

Therefore, in this context of poverty, the development of a good policy of sanitation with the implication of all the factors (state and municipal authorities, communities) is necessary to improve people lives. The results of this study are therefore very interesting database for future actions in the town. They will plan and validate measures to remedy sanitation deficiencies and improve population health.

As shown in Table 2, majority of the respondents (94\%) are concerned about the volume of waste presently generated in the State; an indication of an increase in environmental awareness among the citizenry but lack environmental consciousness as reflected in their attitude to waste generation and disposal (Egun, 2010).

Pertaining to the purchase of and use of recycled waste, majority of the respondents (78\%) responded positively as they were supportive of waste recycled products especially for plastic/ polythene products which is a major concern in the State; $11 \%$ of the respondents gave a negative response as they were of the notion that recycled products will not be durable and efficient as their un-recycled counterparts; and $11 \%$ of responses were uncertain, which could be attributed to their lack of knowledge about the concept of recycling. The use of compost fertilizer had $85 \%$ positive response and uncertain response of $15 \%$. The high positive response is attributed to their background knowledge of cultural agricultural practices.

Awareness on the concept of waste separation before disposal showed a poor positive response (17\%) and a high 
negative response (83\%), an indication of lack of sensitization and enlightenment on the need for proper waste segregation before disposal, as present enlightenment done on waste management has been centred on proper disposal of waste using waste bins/ tanks with the aim of preventing water erosion and flooding as a result of waste blockage of water drainages; and having a cleaner environment. Those who responded positively to waste separation/ sorting before disposal where mostly those who have had the opportunity of living in the Western/ developed countries where it is been practiced; and are not presently doing so because of the absence of adequate facilities.

Also, on the issue of participation in the waste market operation; $87 \%$ of the respondents gave a positive response, $5 \%$ responded negatively and $13 \%$ of the respondents were uncertain. Those who responded negatively saw the job as demeaning, which can be attributed to the present perception of the job. Those who responded positively have been involved in the waste market operation indirectly as they have on several occasions sold household recoverable waste such as bottles, metal scarps, newspapers and abandoned electronics to waste pickers/ scavengers for a token amount of money or in exchange for other useful household items; and would be encouraged to participate more if Government provide certain incentives necessary to make the market lucrative. Table 2 indicates respondents' replies to issues affecting waste market operation.

Table 2. Respondents replies to issues affecting waste market operation

\begin{tabular}{|c|c|}
\hline \multicolumn{2}{|c|}{ Parameter Percentage (\%) } \\
\hline $\begin{array}{l}\text { 1. Concern about the volume of } \\
\text { waste generated. }\end{array}$ & \\
\hline Yes $(94 \%)$ & No $(6 \%)$ \\
\hline $\begin{array}{l}\text { 2. Purchase of products made from } \\
\text { recycled waste }\end{array}$ & Yes 78 \\
\hline No $(11 \%)$ & Uncertain (11\%) \\
\hline 3. Use of Compost Fertilizer & Yes $85(\%)$ \\
\hline No - & Uncertain 15 \\
\hline $\begin{array}{l}\text { 4. Participation in Waste Market } \\
\text { Operation }\end{array}$ & Yes 87 \\
\hline No 5 & Uncertain 13 \\
\hline $\begin{array}{l}\text { 5. Awareness on the concept of } \\
\text { waste separation before disposal }\end{array}$ & Yes 17 \\
\hline No 83 & \\
\hline Parameter Percentage (\%) & $\begin{array}{l}\text { 1. Concern about the volume of } \\
\text { waste generated. }\end{array}$ \\
\hline Yes 94 & No 6 \\
\hline $\begin{array}{l}\text { 2. Purchase of products made from } \\
\text { recycled waste }\end{array}$ & Yes 78 \\
\hline No 11 & Uncertain 11 \\
\hline
\end{tabular}

With an average of 10 persons per household, we have a size of 1000 people. Data collected in health facilities, were from 15 health centers spread over the town with a size of
124446 people with diseases such as malaria, diarrheal diseases and acute respiratory infections.

\subsection{Sources of Population Water Supply Sanitation}

It appears from our investigations that about $60 \%$ of households used self purification works. Defecation in nature was used too in the town (2\%). Anarchic connections to the sewer system were observed especially in precarious living quarters (12\%). Collective purification works systems were used in approximately $26 \%$ of cases. However, misuse of collective purification works (anarchic connections to the sewer system, dumping of domestic waste into the drains rainwater) lead to the fact that wastewaters were hardly drained. This causes the stagnation of sewage, proliferation of larval gites and strong emissions of foul odors.

\subsection{Prevalence Rate of Some Diseases and Health Center Attendance}

The prevalence rate of malaria, diarrhea and acute respiratory infections of 124446 people received into consultation in 15 health centers in the town indicates that among all these diseases, malaria diseases were much contracted by people with $58 \%$ of cases. After malaria, we have acute respiratory infections (ARI) with $28 \%$ of cases. Diarrheal diseases were the least contracted for entire population with $14 \%$ of cases. Moreover, we have noted that under-five children often contracted malaria with $69 \%$ of cases. Unlike the general population, diarrheal diseases were much contracted by under-five with $26 \%$ of cases.

Lagos State has serious challenges with its waste management from generation through storage, treatment, to disposal; non availability of enough storage facilities, treatment technologies, and good methods of disposal for its waste. The problem of solid wastes in the State that has become an intractable nuisance is the indiscriminate dumping of refuse, as citizens continue to exhibit apathetic and lackadaisical attitudes towards matters relating to personal hygiene and environmental cleanliness, of which waste management in general is its focus, and should not be over looked.

\section{Conclusion}

Data collected in various centers in the town on cases of morbidity, revealed that malaria is much contracted by populations with $58 \%$ cases against $14 \%$ for diarrhea and $28 \%$ for acute respiratory infections. Under-five children are much affected with $24 \%$ of the patients among which $43 \%$ were cases of the diarrheic diseases. Also, malaria and respiratory infections are more important during rainy seasons, in contrast to diarrheal diseases caused by poor hygiene of people. Government should not only conceive waste management as service but a war against poverty and poor living environment for actualization of oneself. Education level affects public health of the populace. Waste 
creation is part of human endeavor but the disposal will be neglected until Government creates incentives, preferably market - based incentives that will encourage both people and enterprises to dispose their waste in an appropriate way. This is paramount because the implication of proper waste disposal has led to a huge expenditure on public health, reduction in productivity of the populace and reduction of life expectancy. Today, when waste management service is delivered and cost paid for by the generator (providing employment), it means waste has provided wealth too and can be construed as waste-to-wealth. With this extension, effective waste management has become not only service but an instrument for fighting poverty.

Finally, sanitation situation in Lagos town is very worrying. In different living quarters of the town, human excreta are disposed of either in sanitation facilities, or in collective purification works, or in nature. However, misuse of these facilities causes the stagnation of sewage in the streets of neighborhoods, with escape of strong foul odors and proliferation of larval gites. These are all problems that threaten the health and well-being.

In terms of drinking water, the populations surveyed use a lot of water of lagos for domestic needs. Unlike the wells, they are used to lesser degrees. Regarding the health status of populations, recurrent illness in Lagos includes malaria, diarrheal diseases and acute respiratory infections. The rates for malaria and respiratory infections are most important during the rainy season, in contrast to diarrheal diseases that are caused by poor hygiene and risk behaviors of populations.

There is no doubt that, given the diversity of material coming under the heading of waste, there is considerable potential for hazardous exposure to occur through waste management. High levels of contamination of air, soil and water in a few well publicized situations have led to widespread unease about the potential health effects of waste management processes, particularly within communities living in the proximity to relevant sites.

Also it should be noted that under-five are affected by these pathologies especially malaria, which is much contracted by this section of the population. Sensitization on good hygiene practices and good policy of municipal authorities for sanitation is essential to improve people lives. The results of this study will be particularly useful to health authorities and municipalities. The town can be used as tools to raise public awareness on good hygiene practices and sanitation.

\section{Recommendation}

Legislation: Although the Federal government has taken adequate legislative steps to tackle environmental problems, including solid-waste management such as the setting up of the Federal Environmental Protection

Agency (FEPA) (FEPA, 1990). Establishment of State Environmental Protection Commission (EPC) to complement the efforts of FEPA in the State. However, much success is yet to be achieved, largely because of the weakness of the enabling legislation and the inability of the relevant agencies to enforce some of the laws, leaving much to be desired.

Government should come in to harness the abundant manpower of scavengers/ waste pickers by providing safety complaint wears and working instruments to make the working environment safer and encouraging for the participation of youths thereby creating employment. Their role in the reduction of waste in dump sites should and must be captured in the planning of effective solid waste management and waste marked operations as they can be incorporated in the proposed waste separation - collection system which is the primary backbone and the initial driving force/ commitment needed to be made by the government to make available various waste materials as precursor and additive raw materials for industries.

The health impacts of new waste management technologies and the increasing use of recycling and composting will require assessment and monitoring

\section{Acknowledgements}

We thank officers of the Lagos Waste Management Authority and copious individuals for their important contribution and notable impact to the success of this research.

\section{REFERENCES}

[1] Waste \& Resource Management. March 2010. Crown Press, London.

[2] Enete, I. C. (2010).Potential Impacts Of Climate Change On Solid Waste Management In Nigeria. Earthzine. Posted on October 4th, 2010.

[3] Federal Republic of Nigeria Official gazette (2007). Report of 2006 National Population Census No. 24, vol. 94, 2007, pp. B52 - B53.

[4] Gowan, T. (1997). "American Untouchables: Homeless Scavengers in San Francisco's Underground Economy". International Journal of Sociology and Social Policy 17 (3/4): 159.

[5] Health. Sci. Eng., Vol. 6, No. 3, pg. 173-180 173.

[6] Hoornweg, D., Thomas, L., and Otten, L., (1999). Composting and its applicability in developing countries. Urban waste management working paper series 8 .

[7] Martin, M. (2007). The World's Scavengers: Salvaging for Sustainable Consumption and Production. New York:Altamira Press.

[8] Nabegu, A. B (2010). An Analysis of Municipal Solid Waste in Kano Metropolis, Nigeria. J Hum Ecol. Vol. 31(2): 111-119. 
[9] New York State Department of Environmental Conservation, (2004). Components Of Modern Municipal Solid Waste Landfills Environmental Containment System.

[10] Norton, J. W, (2005). Environmental Balance: Norton incinerator specifications.

[11] Online:http://www.environmentalengineering.net/incinerators specs.php

[12] Online:http://www.dec.state.ny/website/dshm/sldwaste/lfxse ct.htm.

[13] Ogbeide, H.E, Uyigue,E,(2000). Medical Waste Management. Society for Water And Public Health Protection.

[14] Online: swaphep.virtualactivism.net/text/manualon.medicalwaste.do $\mathrm{c}$

[15] Ogedengbe, M.O (2001). Waste Management Systems Potential Impacts. Paper Presented During a Course on Environmental Impact Assessment by National Centre for Technology Management, OAU, Ile-Ife.

[16] Ogwueleka, T. C. (2009). Municipal Solid Waste Characteristics and Management in Nigeria. Iran. J. Environ.

[17] Olafimihan, O.A, (2005). Oral Interview Wastes
Management Practice At Obafemi Awolowo University Teaching Hospital Complex, Ile-Ife.

[18] Ontario Ministry Of The Environment, (2002). Design And Operation Consideration For Biomedical Waste Incinerators. Online:

http://www.ene.gov/.on.ca/envision/2p/1310e02.htm.

[19] Oyeshola, D. (1995). Essentials of Environmental issues .The World and Nigeria in Respective. Daily Graphics.

[20] Picken, D.J. (2004) Medical Waste Incinerator. On line: http://www.mw.incinerator.info/en/601

[21] Rotich, H.; Zhao, Y., and Dung, J. (2006). Municipal solid waste management challenges in developing countries of urban waste management systems. International Journal of Technology Management and Sustainable Development, Vol. 5. pp. 257-27.

[22] Zurbrugg, C. (1999). The challenge of solid waste disposal in developing countries, SANDEC News, EAWAG,No. 4, 1999.

[23] WHO European Centre for Environment and Health. Methods of Assessing Risk to Health from Exposure to Hazards Released from Waste Landfills. Lodz, Poland: WHO Regional Office for Europe, 2000 